\title{
From Holy Workers to Profiteers in Luke 20:9-16: The Waning Values of Christian Leadership in Nigeria
}

\author{
Isiorhovoja Osbert Uyovwieyovwe \\ http://dx.doi./org/10.4314/ujah.v20i3.2
}

\section{Abstract}

The paper examines the biblical underpinnings of virtues that should characterised Christian leadership as stewards. The gradual disappearance of these qualities is evidenced in the cheap exchange of the cherished tradition on the altar of mammon. This phenomenon has had its toll on some religious leaders, who unknowingly have goofed from being holy workers to profiteers in God's vineyard. The paper adopts expository approach and critical interpretation of the texts. It discovers that while some leaders have remained faithful as God's servants, others have indulge in the habit of making merchandise of the gospel; bearing ulterior motive as holy profiteers looking for every opportunity to maximise personal gains with caution thrown to the wind. This attitude has not only brought shame and disrespect but disrepute to their persons. Consequently, we have leaders who are depraved indulging in all kinds of vices with unworthy behaviours, such as commercialisation of the gospel, half-baked doctrines and falsification geared towards self-enrichment and woeful threefold manifestation of lust towards wine, women and wealth. The paper therefore concludes by calling on religious leaders to borrow leaf from the life of Prophet Amos who adopted a total denunciation of social evil, rebuking those in political offices sternly without compromise as well as Apostle Paul who set aside all other benefits for the sake of knowing Him, who laboured diligently and earned fame with self-contentment. To shun all forms of undue 
entanglement with worldly affairs, to seek the face of God and play the prophetic and intercessory roles on behalf of the people which is the primary assignment of holy workers thereby restoring the dignity of leadership and the beauty of the vocation.

Keywords: Holyworker, profiteer, mammon, contentment, virtues

\section{Introduction}

One of the most daring challenges facing the church today is that of exemplary leadership, those whom we can actually refer to as $(\varepsilon \rho \gamma \alpha \tau \varepsilon \varsigma)$ labourers. The world has gone deeply rooted in the church, resulting in the loss of true servant-leaders, with proven virtues worthy of being called Christian leaders in a world bedevilled with corruption. This phenomenon brings to bare the challenges and willingness to follow after God in true obedience, clear vision and submission to the call.

The early church amidst persecution demonstrated this $(\alpha \rho \varepsilon \tau \eta)$ virtues by providing efficient leadership even amidst persecution and poverty. Maxwell (2002) contends that the future of the church today has becomes cloudy as a result of poor leadership. This phenomenon has not only beclouds the church but it has short-changed the office leaving it with unworthy appellations that seldom connote her leaders as stewards with heavenly reward for their earthly toils. Boer (1998) holds the account of the leaders within the early church who tirelessly gave their all to ensure that the seed of the gospel was sown.

However, this epoch greatly give in to the era of the $(\alpha \gamma \iota \omega \sigma v v \eta \omega \phi \varepsilon \lambda \varepsilon \varepsilon \iota \alpha)$ holy profiteers who see the vineyard as personal estate instead of stewards, they prefer to remain as profiteers. Vine (1996) notes that the manifestation of desirable qualities which otherwise could be termed godly has beguile many. 
This however does not denote their lifestyle of the believer. The anomaly has been described as 'milk and honey', 'prosperity' and 'easy' life gospel approach. This paradigm has resulted in compromise and diluted gospel messages of romance with sinners being entertained instead of being rebuked within the church just before they turn to the society as $\alpha \gamma \iota \omega \sigma v v \eta \omega \phi \varepsilon \lambda \varepsilon \varepsilon \alpha$, not being worthy ambassadors of the church and the larger society.

\section{Biblical Paradigm of Leadership}

The true sense of biblical leadership today is gradually being traded off due to crazy quest for materialism in place of asceticism. This is because the everyday understanding of who a leader is has been copied copiously thereby losing its savour. Mahoney (2002) contends that yielding to the control of the Holy Spirit is the spring bed upon which the leadership lifestyle is built upon with traits which appeal to the soul for we are His both in nature, words and deed. With reference to the life of Christ in relation to the believers, Mahoney (2002) posits that there are three basic aspects of leadership pattern which model the Christian character. These include: Inward, Outward and Upward blessings. The inward blessing gives joy, love and peace. All these come from within; not based on the present situation or disturbed by circumstances of the individual.

The outward blessings produce patience, kindness and goodness. The life of the leaders is designed to produce patience as a virtue especially in relating with other people otherwise he takes it by force. The leader is oriented towards people with kind acts of bringing relief to others as a measure of assisting the weak and underprivileged within the society as well as goodness.

The upward dimension bothers on the leaders' faithfulness to the call, his commitment and perseverance. Leadership is not a 
war field or political race with the survival of the fittest. The rule of the game requires being faithful as a steward. The privilege of service calls for humility before God and self-control without which it becomes difficult to attain the envied height in leadership; the nexus between one levels of manifestation to the other. It is therefore clear that not all within the sphere of leadership in the church now are called; the prevalence of shamble lifestyle attest to the presence of "holy profiteers". According to Elizabeth Banett Browning (1806-1861), "Earth's crammed with heaven, and every common bush afire with God; but only he who sees, takes off his shoes - The rest sit round it and pluck blackberries." The berry pickers are the profiteers while workers are filled with the upward concern and the zeal to fulfil the Master's will.

Malone (1994) addressed the blackberries attitude among leaders as a total deviation from the call as a steward. This is premised upon the amoral background of leadership and the insatiable quest for material riches. The essence of the tripod stared by Maloney (2002) was to restore mankind back to God in a state of blessed wholeness. In Matt. 22:35-40, here, we see the union and intersection between man, his will and God.

Abogurin (2009) identified the absence of sincerity, selflessness and visionary leadership as the bane of social, political and economic development of any nation. Our emphasis on economic gains/benefits has resulted in the loss of leadership authority. Consequently, some chunks of leaders strive for the economic gains instead of leadership authority. This phenomenon best describes the Pharisaic attitude towards leadership, laying burdens on the people without necessarily sharing any.

Abogurin further notes that leadership should not be seen as a position of reward for the officeholder rather it should be construed as the engine room for the overall development of the 
nation. In similitude after Christ, he mentioned Joseph in the land of Egypt as a man full of vision, compassionate, caring and faithful in his responsibility. Lockyer (1958) adds that he displayed great wisdom, resisted the opportunity to cheat and steal from his master even though he had the ample opportunity. These attributes could possibly afford him the opportunity to impose himself on the people yet, he humbled himself in recognition of this great God.

Idumwonyi (2009) painted the portrait of Deborah as a woman of honour and not mere property according to the Priestly and Yahwistic traditions. She became the third judge in Israel with a heart of boldness, courageous fighter and devotion. She was not deferred by her matrimonial responsibilities neither did she use the opportunities to enrich her household. Like Deborah, Josiah also seeks to know the mind of God. Greenhough J. G. cited in Lockyer (1958) notes that Josiah lived among men who were totally deficient in morals, brains and the combination of wickedness yet he sought after the will of God. His decision brought him to the lime light like a diamond, a spark in the dark. He purged Judah and Jerusalem with his reformation; a cleansing of the nations along with the restoration of temple worship at its completion.

The great Apostle Paul serves as another model of leadership in the Bible. Lockyer (1958) identified among others that the man Paul put into use his strict religious training without compromising standard. His missionary zeal both in Judaism and Christianity led to the expansion of the faith. After the Damascus experience, he remained a devout and strong adherent of his faith working with zeal, not counting on materialism but the excellency of the faith and knowledge of Christ as true riches.

Timothy was a young man from Lystra, he shared much in common with Apostle Paul. As a leader, he was vested with a difficult task as a youth but he did not see it as an opportunity to 
indulge in youthful vices. He had a good confession of faith. He served faithfully holding on to the charge of his master Paul and he served well.

\section{Leaders as God's Stewards}

Gaebelein (1984) notes that the disbelief of the people do not only manifest in their attitude but also in the manner they relate to work. This is why the next pericope x-rayed the attitude towards servanthood. Arguably, they have not accepted the Master's instruction possibly before now so on seeing a fellow servant sent on an errand, they got infuriated. The direct rejection of servants and the denial of the son who is the heir to the throne show the level of greed. "Let us kill him, and the inheritance will be ours" further reveal a sense of memory loss due to overambitious greed and marginal profit tendencies.

Derrett (1970) posits that the violent reactions of the tenants but shows their deep intentions in the vineyard which the Master did not really took note of but later manifested at the time of harvest. Similar behaviour is found among some of our leader who oftentimes would act nichodemusly before the people only to exhibit the strange characters. The love of material gains and promotion made the tenants to act strangely towards the son and the other servants. Leifield (1984) did observed that nothing on earth should warrant such attitude however, it did happened that fellow servants were killed in the process of time. The strange occurrence did buttress the missing link between the life of the Master and the servants. Obodumu (1997) painted a portrait of the scenario in his literary presentation wherein the masses who after casting their votes for would-be leaders they later turned back to torment the people severely. 
Presumably, the quality of time spent in the presence of the Master should have been enough to bring about change both in character, morals and general attitude towards work. The situation however became different at the turn of the son's visit. However, this epoch suddenly gave in to the era of the holy profiteers who see the vineyard as personal estate instead of stewards, they prefer to remain as profiteers. The anomaly has been described as 'milk and honey', 'prosperity' and 'easy' life gospel approach. This paradigm has resulted in compromise and diluted gospel messages of romance with sinners being entertained instead rebuked within the church.

Leadership is a place of responsibility. Therefore, the manner in which leaders go about carrying out their tasks determines if he/she is a steward of the people unto God or not. Often times, there is the temptation to arrogate this privilege by neglecting our task, utilizing the available resources to bring honour and praise to God. The Bible is however replete with scripture attesting to man's status as a steward. This is further established by the fact that a strong relationship exists between stewardship and environment. The lofty positions occupied by man in God's agenda places him above every other creation as the crown. Isiorhovoja and Banwune (2012) contend that the noblest responsibility of man in God's own garden was that of steward (Gen. 1:26; Rom. 8:18-25). They posit that man is not to lord himself over creation but to care for it. The misinterpretation of the word dominion has not only negatively imparted the world but indeed the church.

Moody and Achenbaum (2004) best describe the person of a leader with respect to his duties as a steward. They agree that stewardship wholeness is found among the choicest and dearest virtue which are central to the Christian faith. This idea is further 
corroborated by Rodin (2010) who adds that some leaders have made real shift from being people oriented to mere profit driven. The basic functions of leadership even within God's household now centres on money, money and money again. Thus, the need to redirect our attention towards the concept of Leaders as stewards, a leadership model that is true morally and biblically consistent with the behaviour of the Master.

Rodin introduction of the concept of the Steward Leader is premised on Christ lowly presentation of himself, yet without Him there is no humanity (Philippians 2:7). The process of being a steward, beginning with the heart transformation and the will to do and become all come from him. Hence, he reshape our personalities to conform to His own image, who initiates the process toward being consistent with imago Dei (man in the image of God).

Still from the Pauline perspective, Pascoe (2013) noted the apostle laid more emphasis on the enormity, the nitty-gritty of being called a leader within the church. He quickly drew the attention of his audience to the fact that a leader is the chief servant who must serve the people first both in the community and the church. Among other functions, he is to show God's mysteries and faithfulness (1Cor. 4:1-2), a teacher of the Word (Titus 1:3), accountable to God (1Thes. 2:4) and to care for the churches (2 Cor. 11:28).

In a public show of his stewardship to the people, the leader therefore empowers them the much he can by leading through example the right attitude towards authority, the right value concept through people oriented activities. Jesus got the disciples involved in the process of reaching the world through discipleship and commissioning; the disciples in turn keep enlisting more in the 
church with adequate care and spiritual nourishment. Thus, the church grew under the leadership of James, Peter and John.

\section{Attributes of Godly Leaders}

Quite often, we are concerned with the qualities and functions of leadership. Maxwell (2002) lamented the fact that we commonly applaud and tolerate feelings than standing with the truth. This phenomenon has enthroned some who ordinarily would not have become leaders to emerge. Herring (2012) among other things notes that a Godly leader shows the following attributes:

Being Confident in Christ: The apostle Paul makes this bold statement. "I know whom I have believed, and am convinced that $\mathrm{He}$ is able to guard what I have entrusted to Him for that day"(2Tim.1:12). There is propelling force from within, driving the believer to reaffirm his faith and commitment to the one who has called him to leadership. The ability to stand for the right purpose firmly to the end is an expression of the leaders' confidence. Daniel remained resolute in the land of Babylon, he knew what the king's portion is and decided not to partake in the sumptuous meal served at table. He alongside with the other Hebrew boys chose to remain uncontaminated (Daniel 1:8).

Being Humble: Today, the world has gone gaga looking out for that humble leader who will be true to his followers. Jesus became an enviable example to his followers. He strapped the towel around his waist and washed the disciples' feet (John. 13:1-17). The place of humility has been rightly attested to in various cultures. Isiorhovoja (2017) notes that among the Urhobo people of the Niger Delta, the popular saying, ипиеуovwousekpevwo wan urhe meaning 'being humble-hearted snail crosses over the tree.' The 
Godly leader should be known by his character. Hence among Africans, the proud and the haughty are often not celebrated in the society.

Maintaining Integrity: It becomes an understatement if we begin to cry out loud on the need for leaders to maintain personal integrity. We commonly find in our societies men of low esteem not because they are not full of age but rather, they lack integrity. The Bible holds the account of Samuel's farewell speech to the children of Israel (1Sam. 12:3). He made bold to say that he would repay. How many persons in the position of leadership can make this statement in contemporary Nigeria? Also, the account of Job shows that he was a man of integrity, the ordeal he went through was enough for him to make a change of heart but he did not. His family and friends encouraged, they tried to influence his character yet, and he remained resolute; so confident that his Redeemer is alive.

Always Pressing Higher: It is ungodly to find among persons in leadership position who do not aspire for new height daily. It becomes an error to be appointed a leader who comes to office without an idea of change and innovations. The life of King Josiah remained memorable in the minds of many for the reform he introduced and the restoration of temple worship. Though very young when he became king yet he conquered the gender barrier which has become a recurring decimal in global discourse today. He held an inclusive government where men and women of godly character are empowered. Also, he purged the cities of Jerusalem and Judah of idolatry (Lockyer, 1958). 
A Man of Peace: The word peace becomes a compound word when we discover that it goes beyond the absence of war. It is the manifestation of the innermost thought and expression first, of confidence, trust, assurance, love, patience and self-control. On the contrary too, it encompasses war and battle. In this sense, a man of peace must fight to ensure that the attributes of being a man of peace is not rubbished and misconstrued in the literal sense of it. According to Thomas Jefferson, "In matters of style, swim with the current, in matters of principle stand like a rock" (https://www.monticello.org).

A concise portrait of Desmond Tutu as painted by Allen (2006) revealed so much about him being the rabble-rouser for peace. A religious minister of South African origin who spoke the truth without compromise, a dodged fighter and advocate of peace. He became significant through moral development, resisted the present racism, human right activist, a teacher, a lover and a good listener.

Being Enthusiastic: A godly leader must be enthusiastic, passionate about the office. It has become a common phenomenon among youths today to seek the apian way of attaining success. The society has become anxious, men, women and youths who are driven desperately for quick success. It becomes enigmatic to find youths who are citizens of this country indulging in heinous crimes all for money. Apostle Paul know the spirit of the age, he admonished Timothy to steer clear. (1 Tim. 6:11).

While the world is being driven with crazy passion for materialism, the child of God is driven with enthusiasm. This is the reason why forgiveness and love stands out among Christian leaders because the psyche is not subject to evil vices. Croyle(1997) holds the account enthusiastic account of godly 
leadership. He has shown love and forgiveness to street children, providing shelter, stability and protection to youths otherwise written off by the society. He looks beyond the present in the future of these one.

\section{From Holy Workers to Profiteers}

Many reasons have been adduced for the paradigm shift of leadership interest from that of being workers in the vineyard to profiteers, men reaping the harvest of the Master for personal gains. Russell (1995) expressed the fear of the present generation readily throwing in the towel when the next generation has not yet mature enough as receive the batting. This phenomenon has constituted major threat to the future of our faith. He further posits that we cannot afford to fail therefore we must put effective and proactive measures in place that will ensure a smooth transition otherwise, we will not be found faithful.

Globally, the church earning is classified under charity. This privilege is has served the church well until the idea of 'Chief Executive Officer (CEO)' came on board. This tendency has led some of the churches to go into huge investment in landed properties both in rural and urban spaces. Ijabla (2016) contends that the exclusion or rather the exemption of churches and its classification under as charity organisations should not be abused by the leadership for self-aggrandizement at the expense of the poor masses who made such contributions. This phenomenon has brought the leadership of the leadership under limelight, calling for proper auditing from external professional bodies with a view to ensuring proper accountability. According to Karl Marx, religion has long been used as an opiate for the oppressed, a palliative measure of giving false hope to the masses. 
The present experiences in the Nigerian context reveal a true picture of what Marxist ideology portrays. Regrettably, the lead have become too hardened and straight-jacketed to give a second thought to the growing volume of riches streaming into the supposed charity fund now being siphoned and mismanaged against the wishes of the majority poor who consist the congregations. Boje (2003) forewarned seminarians on the tendency to be lured under the three powerful W's of 'Wine, Women and Wealth.' The Nigerian media is replete with daily news about high religious leaders who have become infamous for their level of involvement of varying degree of unspeakable activities within and outside the church. Ijabla identified some of the leaders whose assemblies he named as haven for filled with hypocrisy in conduct, financially greedy, fraudulent, mother of all lies, modern day Babylon, gluttons with insatiable desire for material wealth.

Gaffin (1985) notes in his commentary on Phil. 3:17-19 that Paul drew the attention of the brethren who pride themselves so high on the need to live life worthy of the gospel; men and women worthy of emulating by all standards. His admonition becomes imperative because some have departed from the faith yet they maintain fellowship with the church, living in pretension; these persons in the language of Paul are self-centred with insatiable appetites and desires that are often prioritised. They have been rightly identified as libertines. Uniquely like the Pharisees, they encourage other to do what they have not attempted hence the homily is often twisted, based on giving, extensive donations to laudable projects which are geared towards the building of selfempires. In furtherance of the set objectives, sinners become comfortable through their donations and fat tithes, given offices and honoured with titles such as deacons and deaconesses. How far 
can we go? Members who co-laboured in the foundation laying ceremonies are usually pushed aside due to oversight while attention is given to the poor.

The institutions of learning in Nigeria have served as goldmine to religious leaders. The pertinent question here bothers on the initial funding of the projects which is largely raised from the congregation. Its quite pitiable to know that most of these universities charges fees as much as N200.00 and above with all the donations, collections and offerings. The same goes for the secondary schools built with church offerings, donations and tithes of members.

The likes of John the Baptist and Prophet Amos, leaders who did not failed to denounce the social ills of their time, Lockyer (1958), among the Nigerian Christian leaders, there is no room for the poor. The condition is far worse among the Pentecostals whose messages focus on prosperity-preaching and receiving from the poor masses. Their message seldom address the poor state of education or healthcare system in Nigeria neither do they the help in promoting human rights or lead protests against policies that punish asses but reward thieves.

The quest for money bag message has reduced the personality of some leaders now, they find it difficult the speak truth largely because they have become partners in crime. The constant visit to seats of authority, power and closeness to politicians have encourage looting of the national treasury, shabby execution of projects by contractors and non-payment of civil servants' salaries. It would be interesting to know what Jesus thinks of these pastors whose conduct is quite frankly indistinguishable from those of the Pharisees and Sadducees that He described as "brood of vipers" in His days 


\section{Reasons for Waning Values of Christian Leadership}

The waning values of Christian leadership in Nigeria is premised on the inordinate activities that some prominent personalities have indulge in either covertly or overtly. The life of leaders is like a hill visible to all though he may know. The primary reason includes the following:

Loss of Moral Values: Nihilola (2014) gave the pictorial background from Gen. 2:16-17. Though we speak of Adam from the text, the present generation has dealt wickedly beyond any other generation. The leadership of the nation at Independence era had peculiar traits such as hard work, truth, simplicity, contentment, trustworthiness, innocence and peace. Though leadership was not characterized with affluence but it was safe and serene for all to live in. These values were not cherished by contemporary leaders who witnessed virtues such as immorality, virginity as celebrated cultural values. Also, corruption has mesmerized most leaders. Bacchus the gods of wine has led many into drunkenness, mammon the gods of money has been highly enthroned while the spirit of Jezebel has lured many into fornication.

\section{Loss of Self-Esteem}

The quest for leadership positions among believers today has lost the flavour in some quota. While there could be real or genuine reasons for aspiring to leadership positions, the zest for such offices are sometimes lost midway to being there. In verse 14, "let's kill him and take the inheritance." The purpose for which they were engaged has been short-changed midway for personal gains through covetousness. Such passion has driven many in positions of leadership crazy. Cain killed Abel his brother due to 
low self-esteem. The question before him was simple, why did you not do well like your own very brother (Gen. 4:7). The failure to stick with the vision has remained the pitfall of many Christian leaders; the virtue of patience, learning through mentor-mentee process is no longer cherished among believers.

\section{Lukewarmness of Purpose}

The mindset of the owner of the vineyard was to engage capable hands who are ready to run with the vision of managing the vineyard as the owner would have done personally. As the tradition was, the owner should be the first to taste the fruits of his labour. There is a great difference between $\varepsilon \rho \gamma o v$ and $\kappa v \rho i o \varsigma$ worker/labourer and Lord. We see the owner of the vineyard exercising his authority over the workers by demand the first fruits Luke 20:9-10. However the response verses (11-15) is a reaction towards the labourers' lukewarmness of purpose and direct act of insubordination, the unwillingness to submit to the initial purpose and agreement.

\section{Desire to be Like Others}

The longing to own the vineyard was ill motivated. This cannot be far from the ungodly act of covetousness. Weber (1958) best attributes the action to the spirit of capitalism in the labourers that led to their failure to recognize the vital role of servanthood, the most noble calling. More so, they failed to recognize that they have a fixed term of reference with the owner of the vineyard hence they are subject to his dictates.

\section{Loss of the Eschatological Hope}

It is quite important to note one of the choicest pains and gains of servanthood. There is an ultimate reward for them all. This is the 
reason why there is time frame for every servant to gain freedom from the hands of the master. In biblical perspective, what can be addressed as the eschatological hope of the labourers? It is the hope of sharing with the Master ultimately in his kingdom. Adeniji (2014) rightly identified flaws with leadership in the Nigerian context. The individual that clamoured for position yesterday, behaving as a saint before the masses will for sure turn around and become tyranny, despotic and undemocratic by every standard. Similar traits also manifest in the uncharitable manner in which Christians administer the God-given wealth and positions. The missionary vision for the church and mission has been shortcircuited by few individuals in some instances. Missionary hospitals were avenues of evangelism and mission frontiers however, these windows have been so commercialised in some denomination without preference to the poor and needy in the society. Ogelenya (2015) lamented the fact that her wards cannot attend the mission school due to the exorbitant fees payable per child. The continuous quest by the labourers to make merchandise the vineyard has not only brought shame but reproach to her message; laying up treasure here on earth where mot and rot characterised stored treasures. Not until the labourers adopt the pilgrim mentality, the chances are rare for the attainment of this hope.

\section{Conclusion}

The paper does not seek to exalt or o humiliate anybody institution rather, it focused on the loss of servanthood even among Christians who profess faith in Christ and His selfless service to mankind. It considers the get-rich-quick approach of the labourers who ultimately forgot the terms of reference at the point of engagement. The truth of the phenomenon bothers on the fact that we have not 
brought our faith to bear on our vocations as believers. The quest to run and compete with the world for material gains reveal the loss of identity, rejection of the Master of the vineyard, greed and wantonness.

While serving in the vineyard, the Master promised to make provision for our needs (Matt. 6:33, Ps. 23:1). These verses are daily reminder of the grand master plan to promote our wellbeing. These promises however today have been perceived as delayed thus, we have killed, coveted, stolen and branded corruption as a way of life that is acceptable with the body of Christ. In all, we have developed an insatiable quest for worldly goods that our souls have become seared, no longer responding to the things of God and the leadership of the Holy Spirit.

\section{Recommendations}

It recommends among others that: There is the need to rediscover our roots as believers in Christ. It is not enough and sufficient for us to carry placards and signposts, let others see this same Jesus in us. Religious leaders as servants should showcase Christ-like virtues that the world can emulate at all times, bearing in mind that the world lives in darkness and we are the ambassadors of light. The temptations of women, wine and wealth has made many to lose focus of the call as stewards and servants. Remember, Christ did serve even his disciples. No one earthly treasure acquired will count on the last day before the Master, therefore our concern and focus should be stayed on the master's business. Lastly, we shall give account of our stewardship, therefore we must do the work diligently, not as holy profiteers but as holy workers who know the mind of the Master and at the time of his return, we will be commended. 
Isiorhovoja Osbert Uyovwieyovwe

Department of Religious Studies \& Philosophy

Delta State University, Abraka

evanosbert@gmail.com

\section{References}

Adeniji, J. (2014).Nigerian Leadership: The Bane of National Development in Aderinto, O (ed). Nigeria Yesterday, Today and Beyond. Ibadan: Baptist Press.

Allen, J. (2006). Rabble-Rouser for Peace: The Authorized Biography of Desmond Tutu. New York: Free Press.

Croyle, J. (1997). Bringing Out the Winner in Your Child. Benin City: Beulahland Publications.

Darrett, J.D. (1990). Law in the New Testament. London: Longman and Todd.

Gaebelein, F.E. (1984). The Expositor Bible Commentary. Grand rapids, Michigan: Regenecy Reference Library.

Herring, H. (nd). 7 Characteristics of a Godly Leader. Retrieved 24/10/2019 from https://haroldherring.com/blogs/haroldsblogs/richthoughts/21-7-characteristics-of-a-godly-leader. http://saharareporters.com/2016/01/12/thoughts-abuse-andcorruption-nigerian-churches-and-why-religion-cannotreform-world

Ijabla, R. (2016). Thoughts On The Abuse And Corruption In Nigerian Churches, And Why Religion Cannot Reform The World. Retrieved 24/10/19 from

Kamer, J. (2018) Steward Leadership and Paul. Journal of Biblical Perspectives in Leadership, Vol. 8(1), Fall, 126-131 
Leifield, R. (1984). Luke in Gaebelein, F.E.(ed) (1984). The Expositor Bible Commentary. Grand rapids, Michigan: Regenecy Reference Library.

Lockyer, H. (1958). All the Men of the Bible. Grand Rapids, Michigan: Zondervan Publishing House.

Mahoney, R. (2002). The Shepherd's Staff. Burbank: World Map.

Nihinola, E (2014). The church in Nigeria and Moral Decadence: The Way Forward in Aderinto, O (ed). Nigeria Yesterday, Today and Beyond. Ibadan: Baptist Press.

Obodumu, K. (1997). Die a Little. Lagos: Malthouse

Ogelenya, G. (2015). Annotated Lecture Note of Nigerian Nation. Delta State University, Abraka.

Potter, C.F. (1962). The Great Religious Leaders. New York: Washington Square Press.

Potter, F.C. (1962). The Great Religious Leaders. New York: A Washington Square Press Book.

Rodin, R.S. (2010). The Steward Leader: Transforming People, Organisations and Communities. Downers Grove, Illinois: Intervarsity Press.

Russell, B. (1995). May All Who Come Behind Us Find Us Faithful. Ohio: Standard Publishing.

Speiser, M.S. (1989). Ethical Economics and the Faith Community. Houston, Texas: Meyer Stone Books.

Tugwell, S. (1980). The Beatitudes: Soundings in Christian Tradition. Illinois: Templegate Publishers.

Vine, W.E. (1996). Vine's Complete Expository Dictionary of Old and New Testament Words. London: Thomas Nelson Publishers.

Wahab, B. (2018). Top 10 universities owned by churches and their tuition fees. Retrieved 24/10/2019.from https://www.pulse.ng/communities/student/top-10-universitiesowned-by-churches-and-their-tuition-fees/3qz755v 